\title{
A Route to the Synthesis of Aluminium Sulphate from Local Raw Materials
}

J. M. S. JAYATILEKE AND M. G. M. U. ISMAIL

Minerals Technology Section, Ceylon Institute of Scientific and

Industrial Research, (CISIR)

P. O. Box 787, Colombo 7, Sri Lanka

(Date of receipt: 21 December 1982)

(Date of acceptance: 8 March 1984)

\begin{abstract}
The annual requirement of aluminium sulphate in Sri Lanka is about 15,000 metric tons and this is totally imported. Since bauxite is not available in Sri Lanka, Dediyawela ball clay containing about $36 \% \quad \mathrm{Al}_{2} \mathrm{O}_{3}$ and lateritic clays containing about $20 \% \mathrm{Al}_{2} \mathrm{O}_{3}$ were used as sources of alumina for the synthesis of aluminium sulphate. Treatment of calcined ball clay with $\mathrm{H}_{2} \mathrm{SO}_{4}$ results in the formation of aluminium sulphate. The recyclic process of treatment reduced the free acid content in the product. By recrystallisation the excess iron was removed.
\end{abstract}

\section{Introduction}

Aluminium sulphate is available in three different forms as anhydrous $\mathrm{Al}_{2}\left(\mathrm{SO}_{4}\right)_{8}$, $\mathrm{Al}_{2}\left(\mathrm{SO}_{4}\right)_{3} .14 \mathrm{H}_{2} \mathrm{O}$ and $\mathrm{Al}_{2}\left(\mathrm{SO}_{4}\right)_{3} .18 \mathrm{H}_{2} \mathrm{O} \cdot 1$ Commercially available aluminium sulphate is $\mathrm{Al}_{2}\left(\mathrm{SO}_{4}\right)_{3}$. $18 \mathrm{H}_{2} \mathrm{O}$ and it is mainly used in water purification and in the paper industry.

Commercial grade aluminium sulphate is available in two forms. ${ }^{1}$

(a) Iron Free (less than $0.003 \% \mathrm{Fe}_{2} \mathrm{O}_{3}$ )

(b) Commercial Grade $\left(0.4 \%\right.$ to $\left.0.5 \% \mathrm{Fe}_{2} \mathrm{O}_{\mathrm{\jmath}}\right)$

The annual requirement of aluminium sulphate in Sri Lanka is 15,000 metric tons and this is totally imported.

Bauxite is a mineral mainly consisting of $\mathrm{Al}_{2} \mathrm{O}_{8} \cdot 2 \mathrm{H}_{2} \mathrm{O}$. By treatment of bauxite or China Clay with conc. $\mathrm{H}_{2} \mathrm{SO}_{4}$ aluminium sulphate is produced. ${ }^{1,4}$

Mineral bauxite is not found in Sri Lanka.2 Investigations were carried out at the Minerals Technology Section of the CISIR to find out the possibility of using Dediyawela ball clay, kaolin and laterite as a source of alumina $\left(\mathrm{Al}_{2} \mathrm{O}_{3}\right)$ for the production of aluminium sulphate. 
Dediyawela ball clay is an alumino-silicate type of clay and it contains about $36 \% \mathrm{Al}_{2} \mathrm{O}_{3}$.

Laterite is a weathered clay and it contains about $20 \%$ of $\mathrm{Al}_{2} \mathrm{O}_{3}$.

\section{Experimental}

\subsection{Chemical Analysis of Ball Clay and Laterite}

Determinations of $\mathrm{SiO}_{2}, \mathrm{Al}_{2} \mathrm{O}_{3}$ and $\mathrm{Fe}_{2} \mathrm{O}_{3}$ of ball clay and laterite were carried out according to standard methods. ${ }^{3} \quad \mathrm{SiO}_{2}$ content was determined by $\mathrm{HF}$ treatment.

$\mathrm{Al+++}$ and $\mathrm{Fe}^{+++}$contents were determined by spectrophotometry method and the wave lengths of $370 \mathrm{~nm}$ and $700 \mathrm{~nm}$, respectively.

\subsection{Calcination of Ball Clay and Laterite}

Calcination was done using a muffle furnace at different temperatures and periods. The temperature of furnace was measured to an accuracy of $\pm 5^{\circ} \mathrm{K}$.

\subsection{Grinding of Laterite and Ball Clay}

A laboratory ball grinder was used for grinding laterite to pass 80 mesh sieve. Powdered ball clay was obtained from Dediyawela ball clay refining plant of the Ceylon Ceramics Corporation.

\subsection{Acid Treatment}

$98 \%$ analytical grade sulphuric acid diluted to different strengths was used for treatment of ball clay and laterite.

\subsection{Leaching}

Slurry obtained from 2.4 was leached at different temperatures for varying periods, using a steam bath and a magnetic stirrer.

\subsection{Concentration and Crystallization}

Slurry obtained after leaching was filtered under vacuum and the filtrate was concentrated using a steam bath and crystallized by cooling.

\subsection{X-ray Analysis of Samples}

XRD patterns of the samples were taken by using "JEOL JDX-85" type X-ray Powder Diffractometer. 


\section{Results and Discussions}

\subsection{Dediyawela Ball Clay as a Source of Alumina}

Dediyawela ball clay is a mixture of mineral kaolinite $\left(\mathrm{Al}_{2} \mathrm{O}_{3} \cdot 2 \mathrm{SiO}_{2} \cdot 2 \mathrm{H}_{2} \mathrm{O}\right)$ gibbsite $\left(\mathrm{Al}_{2} \mathrm{O}_{3} \cdot 3 \mathrm{H}_{2} \mathrm{O}\right)$ and boehmite $\left(\mathrm{Al}_{2} \mathrm{O}_{3} \cdot \mathrm{H}_{2} \mathrm{O}\right)$. The X-ray diffraction pattern of the Dediyawela Ball Clay (Figure 1) shows the presence of small amount of silica ( $\propto$ quartz) as impurity. The total alumina $\left(\mathrm{Al}_{2} \mathrm{O}_{3}\right)$ content in Dediyawela ball clay is $36^{\circ} \%$ and the chemical composition of the Dediyawela ball clay is given in Table 1 .

Table 1. Chemical Composition of Dediyawela ball clay

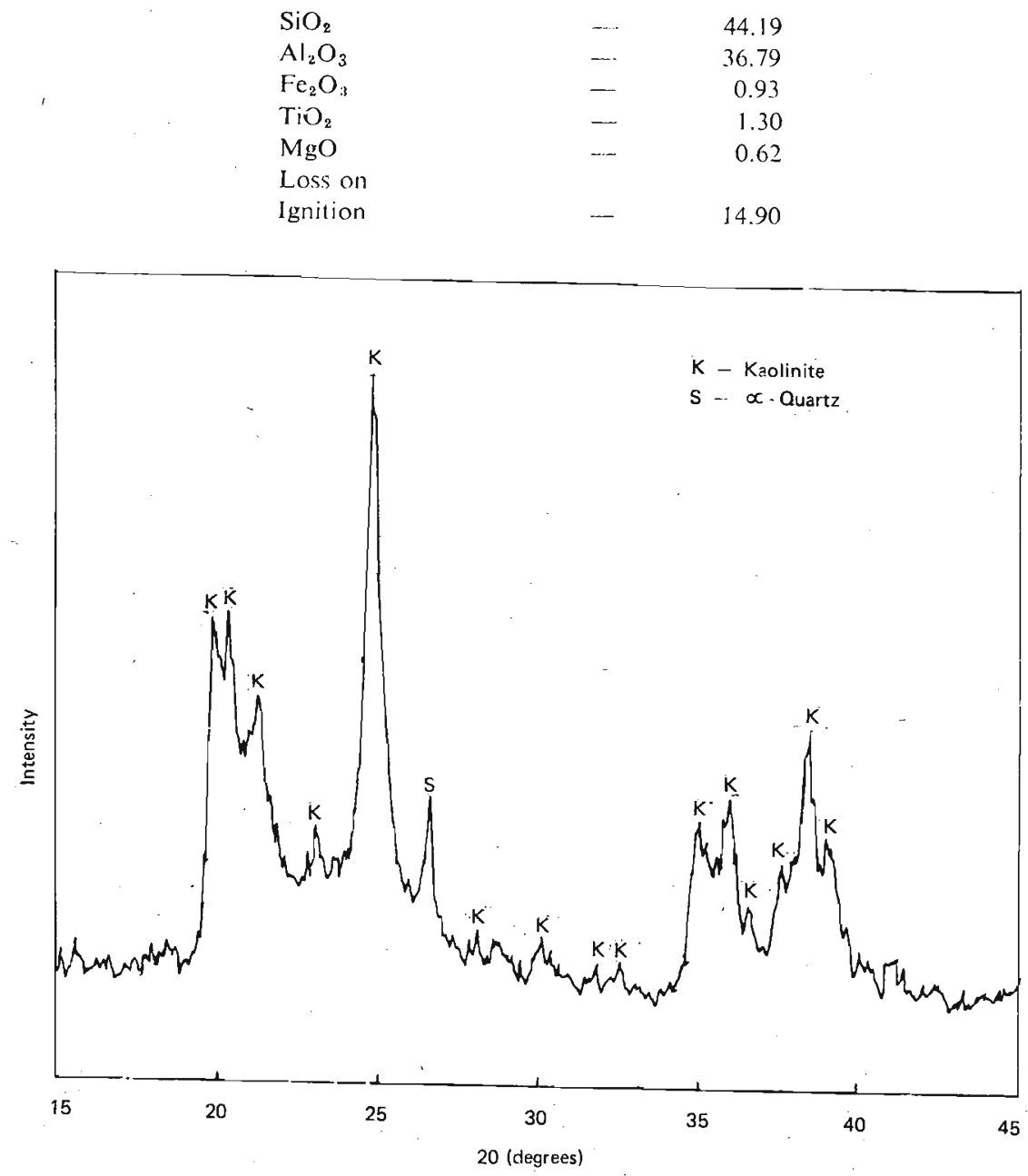

lïgure 1. XRD OI: BALL CLAY. 




焉 
Calcination of ball clay at temperatures above $723^{\circ} \mathrm{K}$ shows the formation of meta-kaolin. The Differential Thermal Analysis curve of ball clay used in this investigation is given in Figure 2. At temperatures above $1198^{\circ} \mathrm{K}$ formation of silicon spinel $\left(2 \mathrm{Al}_{2} \mathrm{O}_{3} .3 \mathrm{SiO}_{2}\right)$ is favoured. The sequence of formation of different types of alumino silicate is given below. ${ }^{5}$

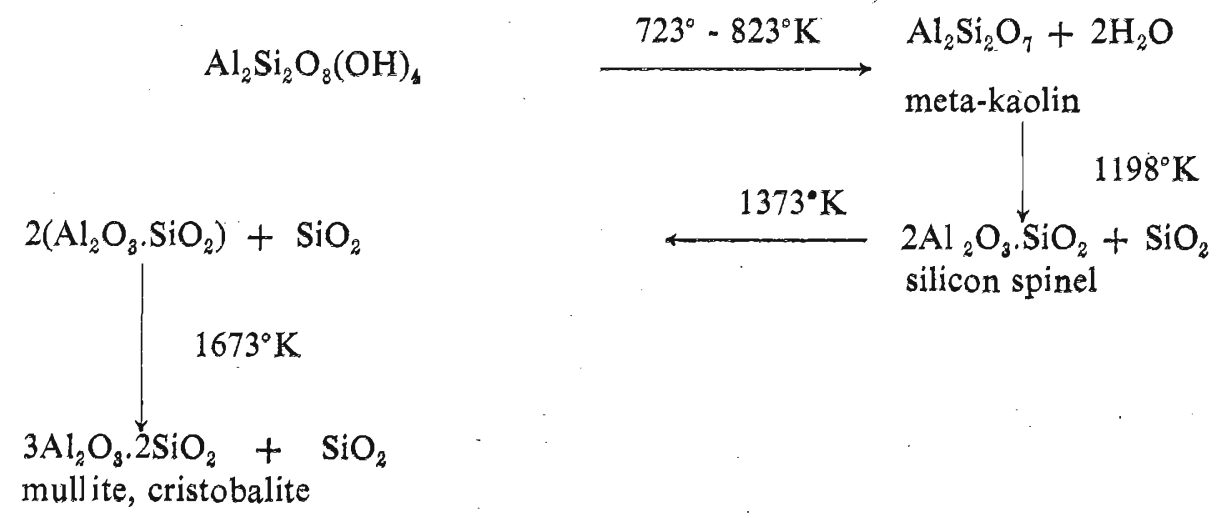

Digestion of ball clay with conc. $\mathrm{H}_{2} \mathrm{SO}_{4}$ at a temperature of $353^{\circ} \mathrm{K}$ resulted in only a very low yield of aluminium sulphate. Treatment of calcinated ball clay with the same quantity of conc. $\mathrm{H}_{2} \mathrm{SO}_{4}$ at $353^{\circ} \mathrm{K}$ gave a better yield of aluminium sulphate.

This experiment clearly shows that the $\mathrm{Al}_{2} \mathrm{O}_{3}$ present in ball clay is in bound form and hence the solubility in conc. $\mathrm{H}_{2} \mathrm{SO}_{4}$ is very low. On calcination, formation of meta-kaolin which is a metastable phase enhances the solubility of $\mathrm{Al}_{2} \mathrm{O}_{3}$ in conc. $\mathrm{H}_{2} \mathrm{SO}_{4}$.

\section{1.l Effect of calcination temperature of ball clay on the solubility of $\mathrm{Al}_{2} \mathrm{O}_{3}$} in conc. $\mathrm{H}_{2} \mathrm{SO}_{4}$

Known quantities $(50 \mathrm{~g})$ of ball clay calcinated at different temperatures for a duration of 2 hours were digested with known quantities $(40 \mathrm{ml})$ of $98 \% \mathrm{H}_{2} \mathrm{SO}_{4}$ diluted to $400 \mathrm{ml}$ with distilled water for a duration of 2 hours at a constant temperature of $338^{\circ} \mathrm{K}$. The filtrate was concentrated and crystallized.

The yield of aluminium sulphate obtained from ball clay calcined at different temperatures was determined and variation of yield with temperature is shown in Figure 3. The results clearly show that the most suitable temperature for calcination of ball clay to yield soluble alumina is $1173^{\circ} \mathrm{K}$. 




Figure 3. Effect of calcination temperature on the yield of aluminium sulphate.

3.1.2 Effect of duration of calcination of ball clay on the formation of aluminium sulphate

Known quantities $(50 \mathrm{~g})$ of ball clay calcined at $1173^{\circ} \mathrm{K}$ for different durations were digested with $40 \mathrm{ml}$ of $98 \% \mathrm{H}_{2} \mathrm{SO}_{4}$ for a duration of 2 hours. The aluminium sulphate formed was crystallized from the filtrate and the weight was determined. The results are shown in Figure 4. Maximum yield of aluminium sulphate was obtained from the sample calcined for a period of 2 hours.

3.1.3. Minimum quantity of conc. $\mathrm{H}_{2} \mathrm{SO}_{4}$ necessary for complete leaching of alumina from calcined ball clay

Dediyawela ball clay calcined at different temperatures was used in this investigation. Durations of calcination and leaching were kept constant throughout this investigation. The results obtained are plotted in Figure 5. In all the experiments the 


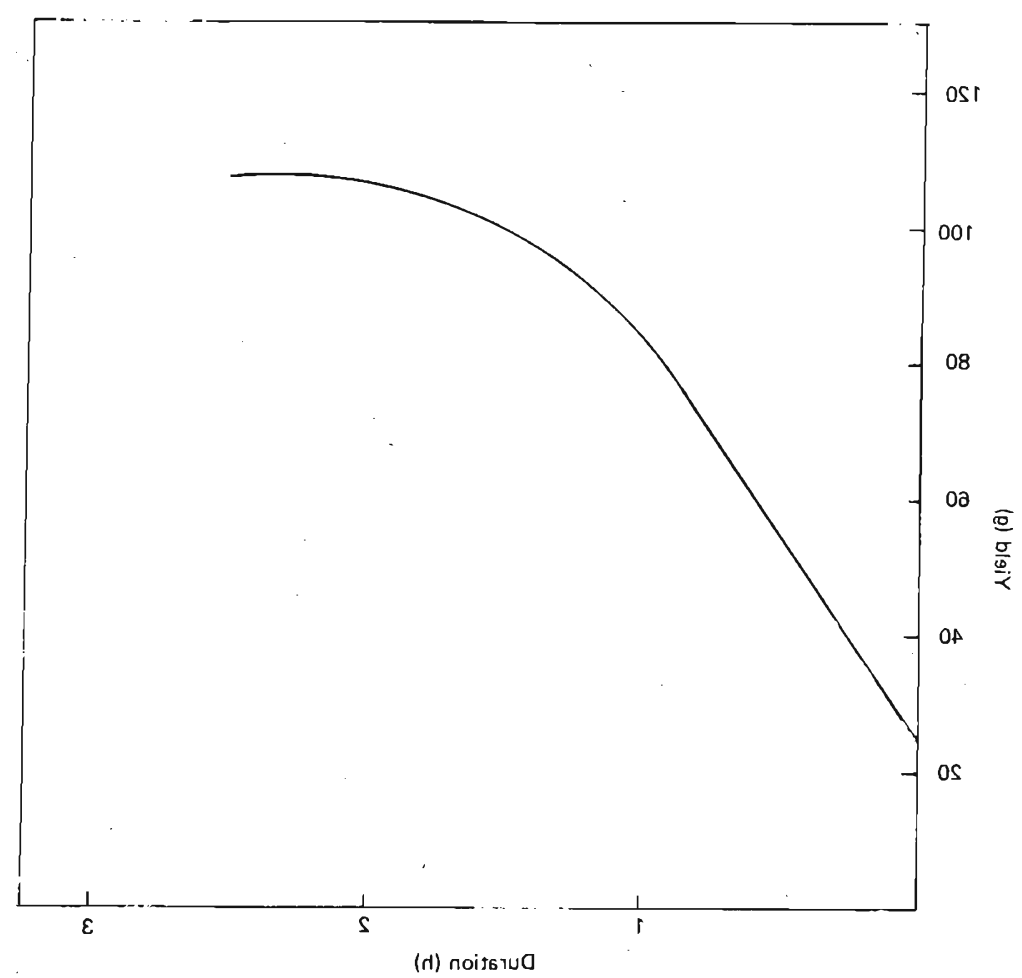

Figure 4. Effect of duration of calcination on the formation of aluminium sulphate.

maximum yield was obtained when ball clay calcined at $1173^{\circ} \mathrm{K}$ was used. It was also revealed that the quantity of $\mathrm{H}_{2} \mathrm{SO}_{4}$ used for leaching is also important in getting the maximum yield of aluminium sulphate.

3.1.4 Effect of temperature and duration of leaching on the yield of aluminium sulphate

Dediyawela ball clay calcined at $1173^{\circ} \mathrm{K}$ was used in this experiment. Leaching of alumina was carried out at two temperature ranges between $338^{\circ} \mathrm{K}$ and $373^{\circ} \mathrm{K}$ using $40 \mathrm{ml}$ conc. $\mathrm{H}_{2} \mathrm{SO}_{4}$ diluted to $400 \mathrm{ml}$ with distilled water for different durations.

The results are shown in Figure 6. Yield of aluminium sulphate obtained increases with temperature of leaching. Complete leaching of alumina was obtained with durations of 2 hours. 


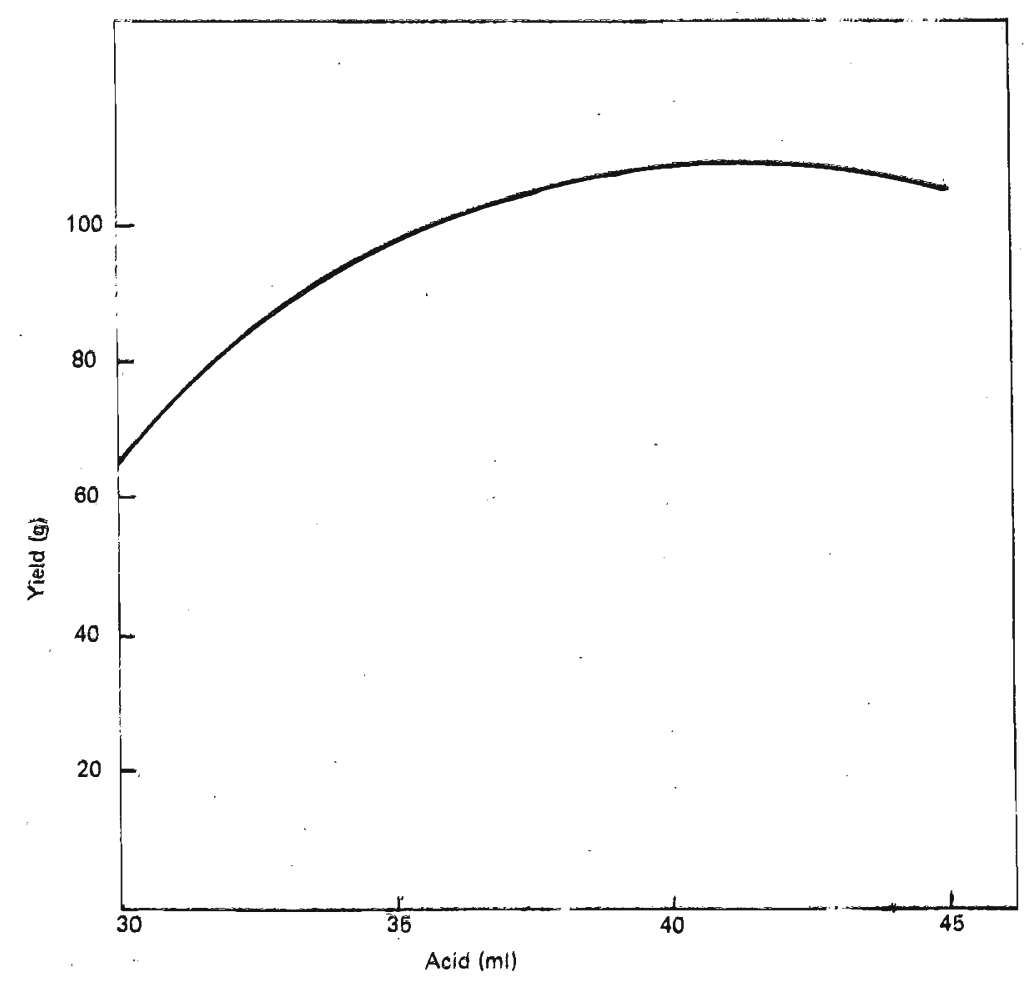

Figure 5. Effect of quantity of Conc $\mathrm{H}_{2} \mathrm{SO}_{4}$ acid on the yield of aluminium sulphate.

\subsection{Laterite type of clay as the starting material}

Laterites are extensively developed in the South-West Region of the island. They are mainly kaolinite clay materials with gibbsite, geothite and silica. Most of the laterites are developed in situ. In addition there are secondary laterites.

Laterites obtained from Kiribedda and Homagama were used in this investigation. The chemical composition of laterites used are given in Table 2. 


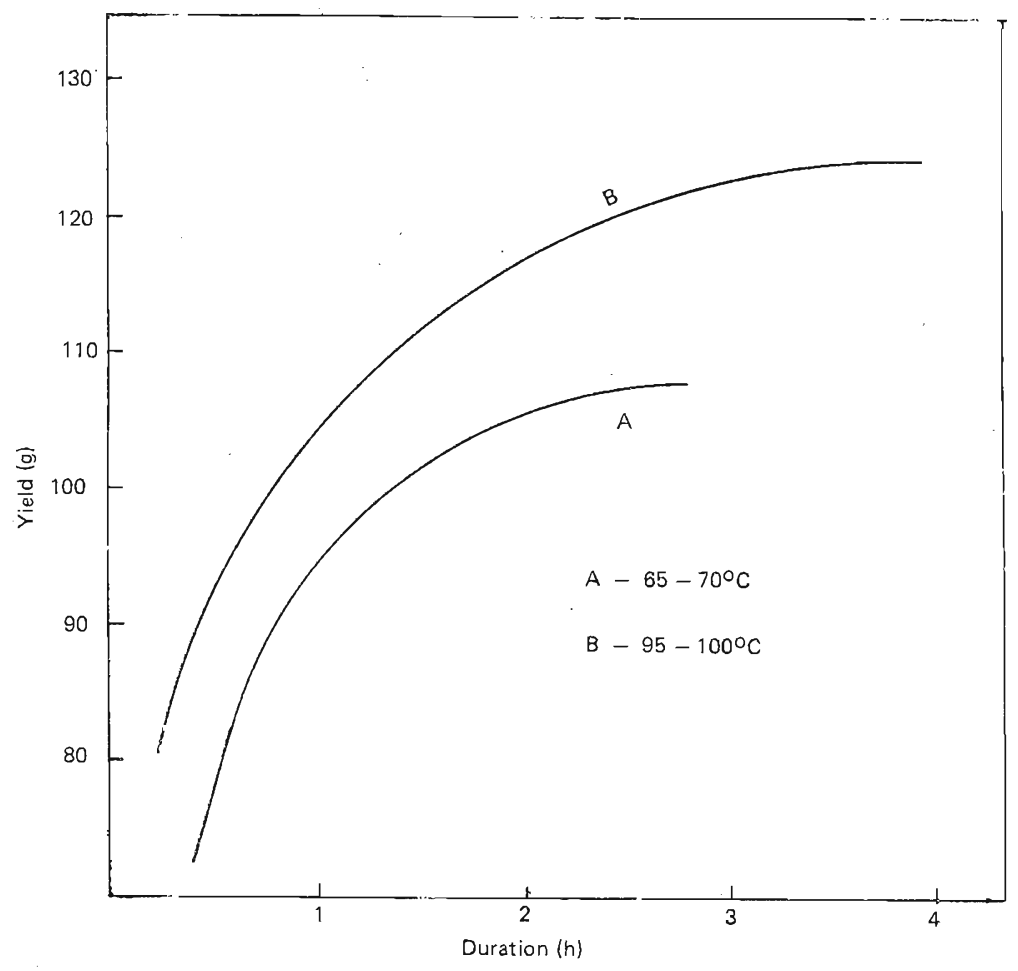

Figure 6. Effect of duration and temperature of treatment on the formation of aluminium sulphate.

Table 2. Chemical composition of laterites

\begin{tabular}{lcc}
\hline Constituent & \multicolumn{2}{c}{$\begin{array}{c}\text { Kiribedda } \\
\text { percent by weight }\end{array}$} \\
\hline $\mathrm{SiO}_{2}$ & 59.22 & 60.82 \\
$\mathrm{Al}_{2} \mathrm{O}_{3}$ & 22.23 & 20.03 \\
$\mathrm{Fe}_{2} \mathrm{O}_{3}$ & 14.56 & 14.15 \\
\hline
\end{tabular}

Quantities of alumina leached using conc. $\mathrm{H}_{2} \mathrm{SO}_{4}$ were very low compared to the total available alumina in laterite. Therefore calcination of laterite at high temperature is necessary to convert the alumina to an acid soluble form. 
3.2.1 Effect of temperature of calcination on the formation of aluminium sulphate

Known weights $(1000 \mathrm{~g})$ of laterites calcined at different temperatures were leached using conc. $\mathrm{H}_{3} \mathrm{SO}_{4}$ and the durations of calcination and leaching were kept constant at 2 hours and 2 hours respectively throughout the experiment. The temperature of leaching was $343^{\circ} \mathrm{K}$ and the volume of $\mathrm{H}_{2} \mathrm{SO}_{4}$ added was $40 \mathrm{ml}$ diluted to $400 \mathrm{ml}$ with distilled water. Maximum yield of aluminium sulphate was obtained from the sample of laterite calcined at $1173^{\circ} \mathrm{K}$. The results are given in Figure 7.

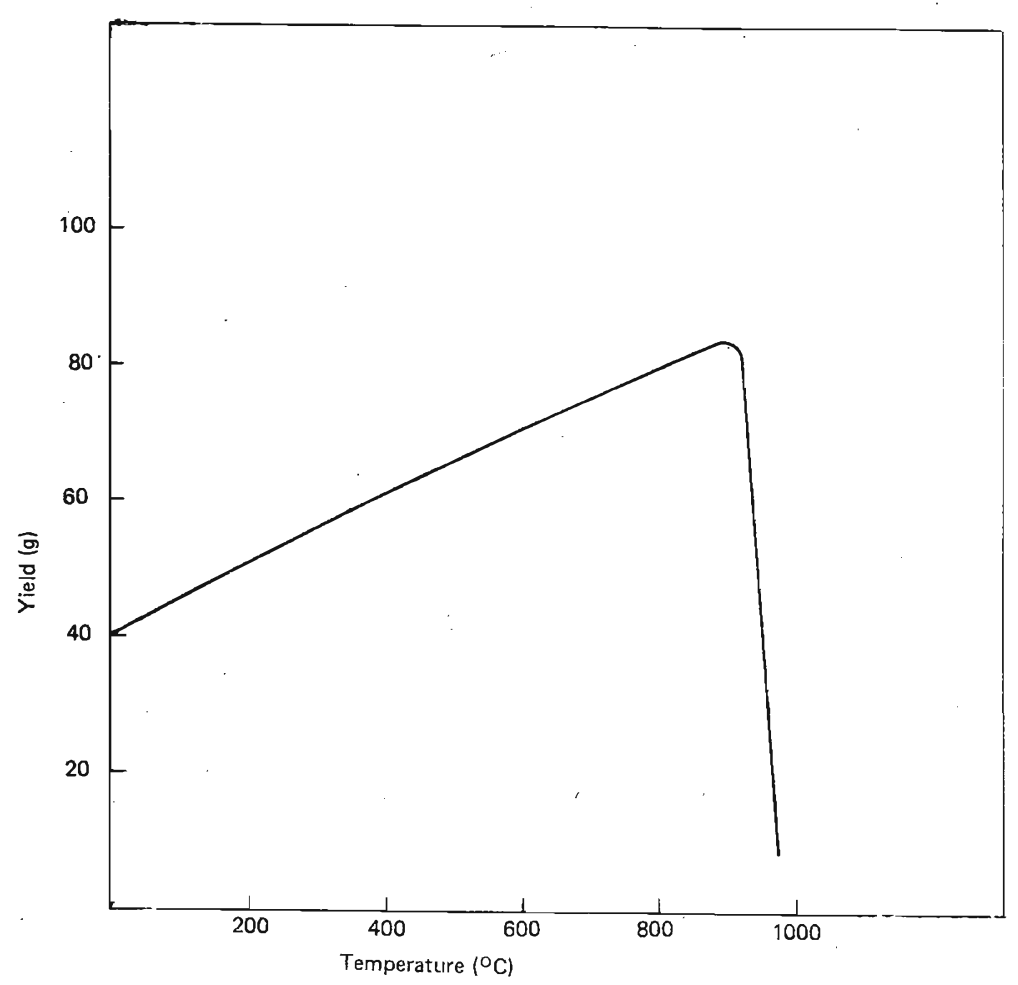

ligure 7. Effect of temperature of calcination on the formation of aluminium sulphate. 


\subsubsection{Duration of calcination of laterite on the yield of aluminium suiphate}

Laterite calcined at $1173^{\circ} \mathrm{K}$ for durations varying from $1 / 2 \mathrm{hr}$ to $05 \mathrm{hrs}$ were used in this investigation. The volume of $\mathrm{H}_{2} \mathrm{SO}_{4}^{-}$added was $40 \mathrm{ml}$ diluted to $400 \mathrm{ml}$ with distilled water.

The results are given in Figure 8. Increase of duration of calcination beyond 2 hours did not increase the yield of aluminium sulphate appreciably.

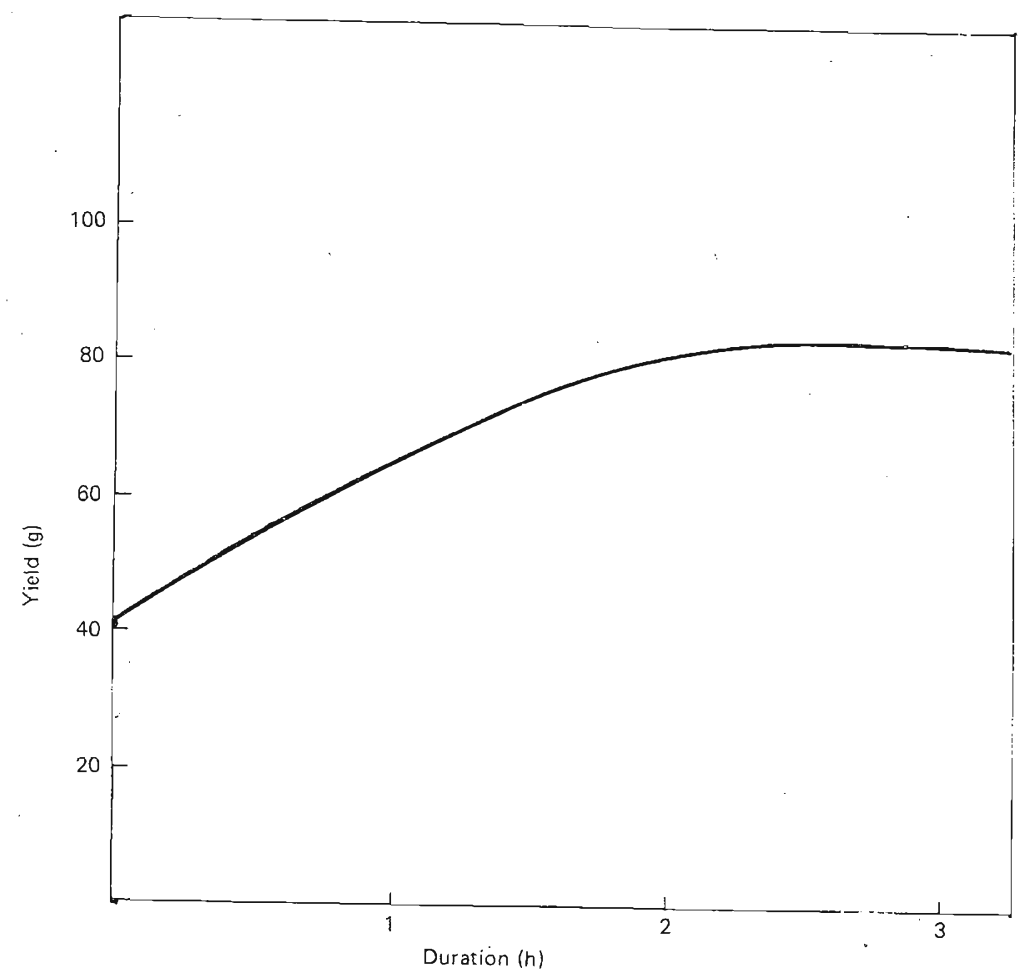

Figure 8. Minimum duration of calcination required for complete conversion of alumina to acid soluble form. 


\subsubsection{Temperature and duration required for complete leaching of alumina}

Laterite calcined at $1173^{\circ} \mathrm{K}$ was used in this investigation. Temperature of treatment was studied at two ranges between $338^{\circ} \mathrm{K}$ and $373^{\circ} \mathrm{K}$. Duration of treatment was varied between 1 and 10 hours The results are given in Figure 9. At temperature of $373^{\circ} \mathrm{K}$ in a duration of 7 hours, maximum yield of aluminium sulphate was obtained.

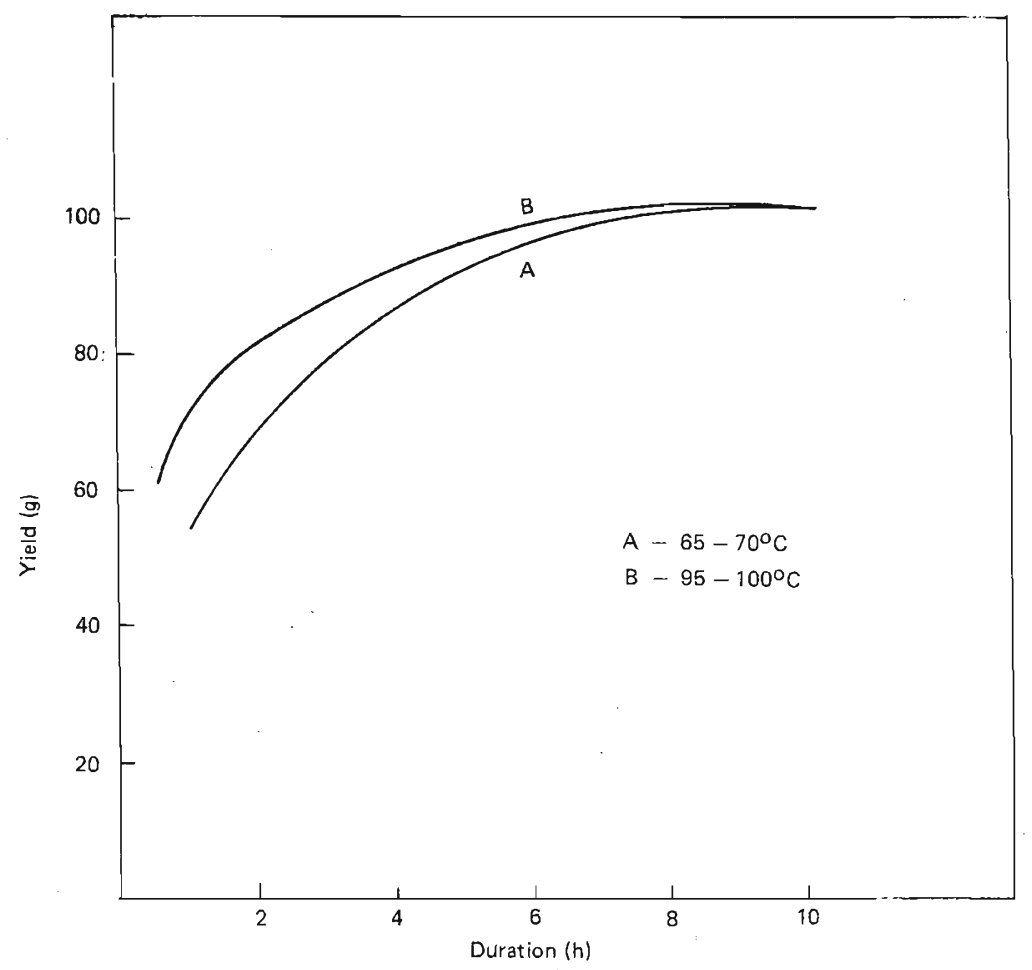

ligure 9. Temperature and Duration required for complete leaching of alumina. 


\section{Discussion}

\subsection{Potential of ball clay as the starting material}

The experiments carried out clearly show that to get a maximum yield of aluminium sulphate it is necessary to calcine ball clay at $1173^{\circ} \mathrm{K}$. Duration of calcination, concentration of $\mathrm{H}_{2} \mathrm{SO}_{4}$ and temperature and duration of leaching are also important factors which affect the final yield of aluminium sulphate. It is also observed that ball clay calcined at $1173^{\circ} \mathrm{K}$ for a duration of $2 \mathrm{hrs}$ when treated with conc. $\mathrm{H}_{2} \mathrm{SO}_{4}$ for 2 hrs resulted in a conversion of about $73 \%$ of alumina present in ball clay to aluminium sulphate.

The X-ray diffraction powder patterns of the commercially available aluminium sulphate and the aluminium sulphate prepared are given in Figure 10. The iron content of the aluminium sulphate prepared $\left(\mathrm{Al}_{2}\left(\mathrm{SO}_{4}\right)_{3} .18 \mathrm{H}_{2} \mathrm{O}\right)$ by the process developed is very low (less than $0.4 \%$ ).

Recycle process of treatment was also tried in order to reduce the free acid in the crystallized aluminium sulphate. The use of excess water in the process of leaching with $\mathrm{H}_{2} \mathrm{SO}_{4}$ resulted in slow crystallization of aluminium sulphate.

\subsection{Potential of laterite as the starting material}

The chemical analysis shows the presence of high percentage of $\mathrm{Fe}_{2} \mathrm{O}_{3}$ which affect the final quality of the product.

To get a maximum yield it is necessary to calcine laterite at $1173^{\circ} \mathrm{K}$ for a duration of 2 hours.

Leaching also has to be carried out under controlled conditions. About $83 \%$ of the alumina present in laterite can be converted into aluminium sulphate. The main impurity observed was iron and by recrystallization the major fraction of iron present in aluminium sulphate was removed as niltrate.

\section{Conclusion}

Ball clay is one of the main raw materials ${ }^{3}$ used in ceramic and rubber industry. The reserves are limited and it is not advisable to use it as the starting material for manufacture of aluminium sulphate, whereas laterites are hardly used as a raw material at present. The disadvantages in using laterites are the low alumina content and high iron content. By carefully selecting laterites of high alumina and low iron content, it may be possible to develop a method for the manufacture of aluminium sulphate. 'It is necessary to carry out pilot plant scale trials before commencing any large scale manufacturing of aluminium sulphate using laterites as the starting material. 


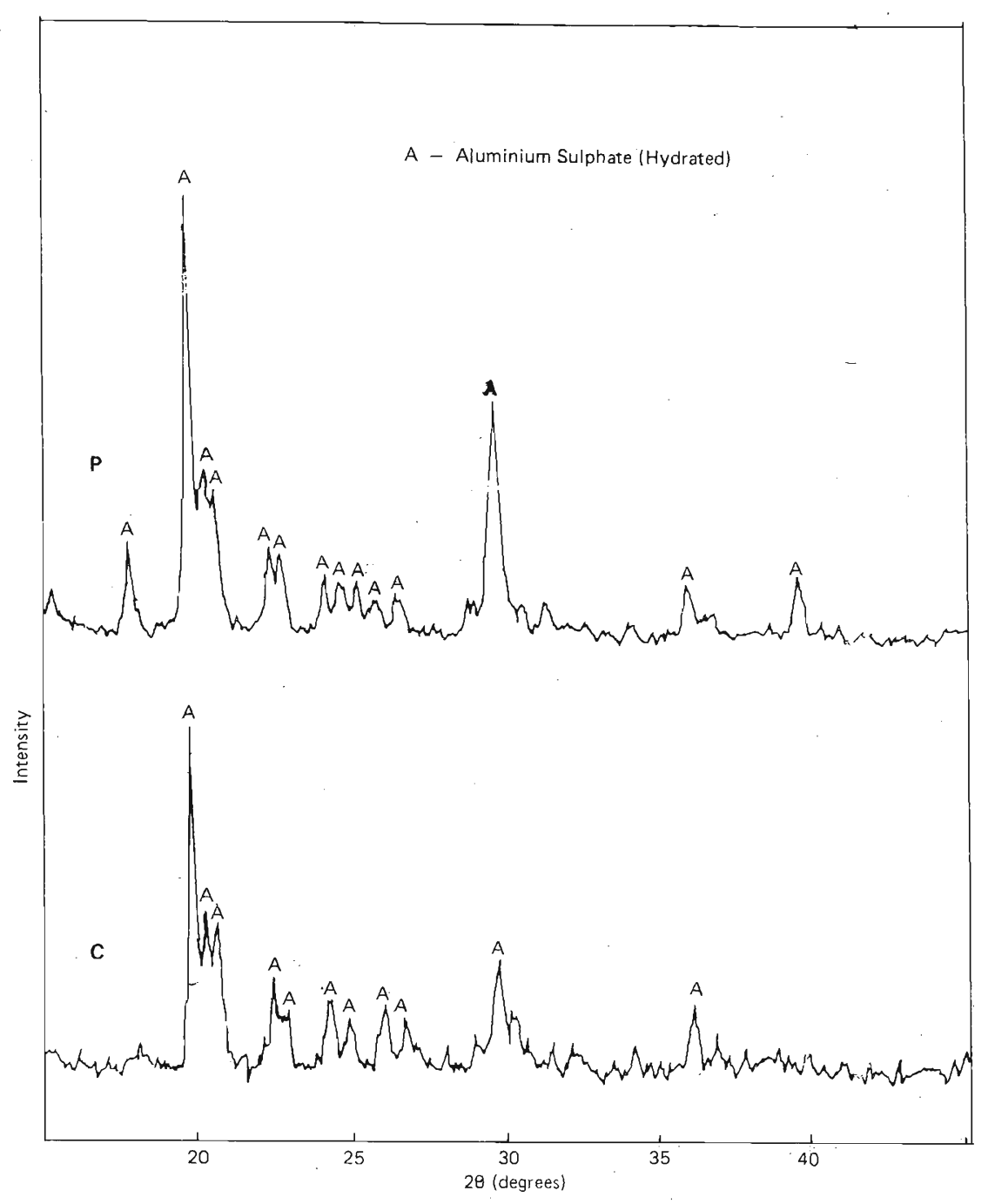

Figure 10. X-ray diffraction patterns of Aluminium Sulphate.

C - Commercial grade Aluminium Sulphate.

P - Prepared Aluminium Sulphate. 


\section{Acknowledgement}

The authors wishes to thank the staff of the Section of Minerals Technology, CISIR, for their kind help given during carrying out the above work.

\section{References}

1. Encichopedia of (hemical lechncilogl, Volume 1 (Copmight 1947). The Interscience Encyclopedia Inc, Neu York pp, 653-656.

2. HERATH, J. W., (1980) Mineral Resourcess of Siri Lanka. Minisiry of Industries and Scientific Atidirs. Democratic Socialist Republic of Sri Lanka.

3. JEFFERY.P.G. (1975) Chemical Methods of Rock Analyis. Second Edition, Perganon Press, Oxford.

4. JOHNSTONE, SYDNEY, J. \& JOHNSTONF, MARCiFRY, (i. (1961). Mincrals for the Chemical and Allied Industries. Second Fitition.

5. WORRAl., W. F. (1908) (las, their nature, origin and general properties Maclarens and Sons, London. 